INTERNATIONAL HIGHER EDUCATION, Number 70 Winter, 2013

Pages 18 and 19

\title{
Nalanda Redux: Is a World-Class University Possible in Rural Bihar?
}

\author{
PHILIP G. ALTBACH
}

Philip G. Altbach is Monan University Professor and director of the Center for International Higher Education, at Boston College. E-mail: altbach@bc.edu.

The Indian and Bihar government, with the support of the East Asian Summit, is resurrecting the 6th century Nalanda University, near its original site in rural northern Bihar. Significant funds have been earmarked for the project, and planning is now under way. Impressive international linkages have already been made. The concept, of course, is wonderful-to recreate in modern garb a true cultural and intellectual treasure of ancient India. The plan for the university focuses on the humanities, social sciences, ecology, and business studies—not the usual engineering and technology emphasis. But some serious practical and conceptual questions need to be asked.

\section{LOCATION, LOCATION}

The site of academic institutions is of key importance. For Nalanda International University, which wants to attract the best and brightest from India and the world, location is of special relevance. Are top students and faculty going to be attracted to rural Bihar? Perhaps, unfortunately, this option is not likely. The best minds want to be in the center of intellectual, cultural, and political life. Scholars want to be able to easily mingle with peers and value easy travel connections. 
The Internet assists scholarly communication, but it does not at all replace human interaction. Top academics value amenities, not only good libraries and laboratories, but also art museums and even an array of attractive restaurants and coffeehouses.

The experience in India and elsewhere, in recent decades, is that it is difficult to build top institutions far from centers. Several of the original Indian Institutes of Technology were located near but not in major urban centers. Thus, there was room to build a campus, while at the same time permitting relatively easy access to a wider intellectual community and to urban centers. Some of the new central universities, as well as the new Indian Institutes of Technology, located away from cities and communities are finding it difficult to attract the best faculty and students.

There are some examples of recently established "green field" academic institutions. Without doubt the most expensive is the King Abdullah University of Science and Technology, located near Jeddah, Saudi Arabia. Located near a large city, benefiting from a multibillion-dollar endowment and an unlimited construction budget, and connections with top universities overseas, its success is not assured. Luring the best academics to Saudi Arabia is not an easy task. It is significant that King Abdullah, who established the university, kept it separate from the Saudi government, with its own budget and endowment. He did not want the new institution to get bogged down in governmental bureaucracy. This example may have some relevance for India.

The Pohang University of Science and Technology, on the other hand, seems to constitute a significant success, although located in a provincial city in South Korea. Just 20 years old, it is well-ranked globally. A private institution, it 
has benefited from the deep pockets of the Pohang Steel Company. The Japanese government located a technological university on the island of Okinawa, far from the Japanese mainland, several decades ago and made a huge investment. Many claim that it is a success, but the jury seems to be out.

Some of the great American public universities may also offer some insights. Most of the best of them were established in the 19th century in or close to urban centers-the University of California-Berkeley, for example, is near San Francisco and the University of Michigan is near Detroit, while the University of Illinois at Urbana-Champaign is in the middle of corn fields. While the latter is a fine university, it is not as distinguished as Berkeley or Michigan—and it suffers when competing for top faculty.

\section{Universities as “Development Projects”}

Governments in many countries decide on the location of new universities for many reasons. Students in an area may not have access to a convenient place to study. A particular region may be in need of investment or development. Or local politicians may have a loud voice. There are often good arguments for placing higher education institutions in locales, where they can contribute to economic growth, student access, or other laudable social goals. India has often been quite successful with this tactic.

However, it is always a mistake to try to locate a top-level research university to meet development goals. The initial investment is large, and the

chances of success are limited. The fact is that the needs of a research university are quite specialized and not comparable to those of an academic institution focused mainly on teaching. 
The new Nalanda's location is dictated by the site of the original Nalanda and not by specific development goals. However, most likely, part of the motivation is to bring resources and modernization to Bihar-there is even talk of moving the site of an airport.

\section{CAN IT WORK?}

The challenges facing the new Nalanda, in its effort to become a world-class university, are daunting. As noted, location is a highly negative factor, perhaps even a determining one. Money may also be an issue-building a top-class university is extraordinarily expensive, especially in a rural and undeveloped location-even with assistance of foreign donors and the central government. Funding for the first stages of development is significant, and levels of financial support must be maintained over time to ensure success. Nalanda International University, as an institution that plans, quite rightly, to stress ecology, development, peace studies, and similar "soft subjects," will find it difficult to obtain recognition in the global rankings, which largely measure the hard sciences. The best tactic here is to forget about the rankings, but this is not an easy thing to do. The involvement of many agencies, of both state and central government, may create bottlenecks and bureaucracy-which often seems to be the case in India, as well as elsewhere.

Perhaps the best course of action would be to keep the name and the spirit of Nalanda but move the university to a more practical location. 